SPARKS, Randy J.

\title{
Where the Negroes Are Masters: An African Port in the Era of the Slave Trade
}

Cambridge, Massachusetts and Londres:

Harvard University Press, 2014. 309p.

Carlos da Silva JR.

Doutorando Bolsista Marie Curie/European Union

Wilberforce Institute for the study of Slavery and Emancipation (WISE)

University of Hull

Hull, UK, HU67RX

carlos@eurotast.eu

A participação das autoridades africanas era indispensável para o bom funcionamento do comércio transatlântico de escravos. Ao longo da costa ocidental africana, a presença europeia reduzia-se a poucos fortes litorâneos, sempre sob a vigilância dos potentados locais. A estes cabia a aquisição dos cativos no interior, o transporte para o litoral e sua venda aos comerciantes europeus. O livro de Randy J. Sparks, Where the Negroes Are Masters ("Onde os Negros são senhores"), lança um olhar sobre essa questão a partir um importante porto, embora pouco estudado, do tráfico de escravos: Annamaboe (ou Anamabu, em português), durante o século XVIII. De uma pequena vila de pescadores no final do Seiscentos, Anamabu converteu-se no principal empório escravista na Costa do Ouro (atual Gana) no século XVIII, segundo estimativas do banco de dados Voyages (www.slavevoyages.org).

Recebido 9 de setembro de 2014 | Aprovado 13 de dezembro de 2014 http://dx.doi.org/10.1590/0104-87752015000100011

Varia Historia, Belo Horizonte, vol. 31, n. 55, p. 287-290, jan/abr 2015 
Em livro anterior, The Two Princes of Calabar (Harvard University Press, 2007), Sparks investigou a trajetória de dois membros da elite de Old Calabar (Velho Calabar), no golfo de Biafra, pelo mundo atlântico. Amparado em ampla pesquisa documental, o autor agora analisa o comércio negreiro na Costa do Ouro, suas relações com as autoridades africanas, os "senhores" de Anamabu, e com o mundo atlântico do século XVIII.

Entre outros méritos, Where the Negroes Are Masters contribui para os estudos do Atlântico Negro, "que compreensivelmente tem se focado no tráfico de escravos e suas milhões de vítimas, mas tem prestado menos atenção às elites comerciais africanas que facilitavam aquele comércio e eram tão essenciais para a economia atlântica quanto os comerciantes de Liverpool, Nantes ou Middelburg" (p. 6). Sparks investe, portanto, nas histórias de indivíduos - especialmente dos africanos - que participaram, em maior ou menor grau, do comércio negreiro em Anamabu.

Não por acaso, dois capítulos tratam de figuras-chave para o tráfico de escravos e que permeiam todo o livro: John Corrantee e Richard Brew. Este, funcionário britânico da Royal African Company (RAC) e mais tarde mercador particular (quando a RAC foi substituída, nos anos 1750, pela Company of Merchants Trading to Africa, ou CMTA) cuja carreira em Anamabu durou mais de vinte anos até sua morte em 1776; aquele, comandante militar africano e mais importante caboceer (do português cabeceira, literalmente "capitão", título aplicado a altos dignatários) de Anamabu até seu falecimento em 1764. A diplomacia era peça essencial em Anamabu, e ambos utilizaram-na, cada um à sua maneira. Corrantee envolveu-se profundamente nos negócios do tráfico e usou a rivalidade entre as nações europeias (França e Inglaterra, notadamente) em proveito próprio. Richard Brew, que na década de 1760 era o maior exportador de escravos na Costa do Ouro, fez uso de sua influência para mediar conflitos tanto entre os britânicos e as autoridades locais quanto entre as principais entidades políticas na Costa do Ouro: os Fante, que controlavam Anamabu, e os Achante ou Axanti, principais fornecedores de escravos do interior. 
As nações europeias tentavam a todo custo ganhar o favor de Corrantee. Os franceses queriam construir um forte em Anamabu, mas os ingleses, que já tinham um forte ali, tentavam evitá-lo de todas as formas. John Corrantee manipulou habilmente os interesses comerciais europeus em seu favor. Graças a suas manobras diplomáticas, ele pôde enviar seus dois filhos à Europa para receber educação formal. A vida desse negociante demonstra a complexidade das relações entre comerciantes europeus e mercadores africanos na costa africana durante o século XVIII. Aliás, como astutamente nota Sparks, "Corrantee e seus companheiros caboceers deveriam ocupar um lugar central na historiografia do tráfico de escravos" (p. 67).

Richard Brew, por sua vez, logo percebeu que uma das chaves para o sucesso em Anamabu estava em estreitar laços com as elites locais, o que fez através do casamento com a filha de John Corrantee. Ele formou, segundo palavras de Randy Sparks, uma "família de crioulos atlânticos" (p. 68). O conceito, emprestado do historiador Ira Berlin, aplicava-se aos africanos adaptados às línguas, modos, valores e culturas dos europeus no litoral ocidental da África. Uma alternativa à noção de "crioulos atlânticos" é o conceito de "ladinização". Empregado primeiramente por João José Reis para o caso dos libertos baianos no século XIX (Domingos Sodré, um sacerdote africano, Companhia das Letras, 2008), ele serve sem dúvida para explicar as dinâmicas sociais e culturais na Costa do Ouro (e na costa ocidental da África como um todo) no século XVIII. Ao aprender a língua europeia e enviar seus filhos para obter educação formal (ou formar uma família com mulheres locais, no caso dos europeus), esses africanos "ladinos" aprenderam os mecanismos de negociação com as diversas nações europeias, sem tornarem-se necessariamente "crioulos" no sentido cultural.

Nos capítulos seguintes, Sparks aborda temas caros à historiografia africanista mais recente, como a origem dos africanos deportados via tráfico transatlântico, a circulação de africanos e sua articulação dos portos africanos com o mundo atlântico. No primeiro caso, punições judiciais, raptos, a prática de "panyarring" - escravizar um devedor ou um parente seu até que a dívida fosse sanada, sob pena de colocá-los 
em escravidão permanente - e o "pawn" ("penhora humana”) cumpriam papel importante no suprimento de escravos. Contudo, a maioria dos escravos foi capturada em guerras promovidas pelos Achante no interior da Costa do Ouro. Quanto à circulação através do Atlântico, marinheiros, escravos, ex-escravos e filhos da elite de Anamabu se deslocavam sob o manto de redes comerciais e religiosas de Anamabu para as colônias inglesas na América do Norte (em especial Rhode Island), Jamaica, Bristol, Liverpool, Londres e outros pontos do mapa do tráfico. No entanto, as mortes de John Corrantee e Richard Brew e os conflitos entre os Fante e o rei Achante contribuíram para desarticular as redes comerciais no porto de Anamabu no ultimo quartel do Setecentos. Por fim, a abolição do tráfico britânico, em 1807, declarou o ocaso de Anamabu, cuja economia se baseava, quase exclusivamente, no comércio transatlântico de escravos.

O livro é uma importante contribuição para a história da África e, ao mesmo tempo, para os estudos de História Atlântica, campo fértil no hemisfério norte mas que no Brasil ainda dá seus primeiros passos. Bem escrito, é livro de leitura fácil, que interessa não apenas ao leitor especializado, mas também ao público mais amplo. A obra conta ainda com um glossário, facilitando a vida do leitor menos familiarizado com o tema. A constante menção a Corrantee e Brew, ao longo do texto, mais do que simples repetição, enfatiza a importância de ambos no tráfico transatlântico em Anamabu. Pena que este livro, provavelmente, não será traduzido e publicado entre nós, porque no país que mais recebeu escravos do tráfico é muito pequeno o interesse de editoras por livros dessa natureza. 